/// Projekty Prolog (Mazowieckie Centrum Kultury i Sztuki, dotacja z programu Obserwatorium Kultury NCK) i Etnografia/animacja/sztuka (Narodowe Centrum Kultury, Stowarzyszenie „Katedra Kultury”) odbywały się w latach 2011-2012 na południowym Mazowszu, we wsiach Broniów i Ostałówek. Były koordynowane przez Tomasza Rakowskiego (koordynacja merytoryczna), Ewę Chomicką (koordynacja organizacyjna) i Zuzannę Naruszewicz (koordynacja działań lokalnych w projekcie Prolog). Działania projektowe współtworzyła grupa „Kolektyw Terenowy” - Julia Biczysko, Ewa Chomicka, Piotr Cichocki, Aleksandar Ćirlić, Maja Dobiasz, Jarosław Kaczmarek, Zuzanna Naruszewicz, Dorota Ogrodzka, Paweł Ogrodzki, Agnieszka Pajączkowska, Agata Pietrzyk, Tomasz Rakowski, Pola Rożek, Sebastian Świąder - oraz zaproszeni twórcy i animatorzy - Agata Bielska, Piotr Bielski, Gwidon Cybulski, Elżbieta Jabłońska, Lukasz Skapski, Wojtek Ziemilski. Książka dokumentująca całość działań projektowych pt. „Etnografia/animacja/sztuka. Nierozpoznane wymiary rozwoju kulturalnego" ukazała się w maju 2013 roku nakładem wydawnictwa Narodowego Centrum Kultury.

\title{
ETNOGRAFIA/ANIMACJA/SZTUKA. OBRONA METODOLOGICZNA
}

Tomasz Rakowski

Uniwersytet Warszawski

Współczesna sztuka zaangażowana działa często w taki sposób, by podporządkować się efektowi realności działania - by wytwarzać wyraźną zmianę społeczną, tak jak ma to miejsce w działaniach Artura Żmijewskiego (2007). Żmijewski w swoim manifeście pisze wyraźnie, że sztukę może być stać na pewna polityczną dojrzałość, że może domagać się, podobnie jak nauki społeczne czy publicystyka, przebudowywania umysłów, tworzenia nowych warunków życia społecznego, sięgania ku temu, co skuteczne, ku - rzekłbym nawet - pewnej władzy. Sztuka może jednak w ten sposób, jak 
pokazuje, zostać przeniesiona w zupełnie nowe tereny, w miejsca mało dla niej „,bezpieczne”, które nie będą chronione wysoką ranga galerii sztuki czy instytucji artysty, a następnie wprzęgnięta w bezpośrednie działania wobec ludzi z całym ryzkiem tego czynu. Jednak to właśnie wtedy, poza kontekstem swej wysokiej rangi, ogołocona ze swej pozycji w mieszczańskich terytoriach, być może zacznie się sprawdzać jako „silny” język.

Podobnie jednak owa zmiana stymulowana jest przez szeroko rozumianą animację kultury, a więc sztukę wyrastająca z tradycji pracy wśród społeczności, community arts, sztukę pierwotnie kontrkulturowa, walcząca, punkowa, a obecnie coraz bardziej pragmatyczną i zinstytucjonalizowana, i, podobnie jak sztuka współczesna, rozpięta pomiędzy ,powinnościa a buntem" (zob. Żmijewski 2007:16-17). Animacja kultury, korzystająca z narzędzi sztuki, kieruje się zatem w stronę budowania nowych, pozytywnych relacji społecznych i wytwarzania nowych elementów rozwoju wspólnoty (zob. m.in. Crehan 2011; Matarasso 2009; Ptak 2008, Rogozińska 2009). Zarówno sztuka współczesna, jak i adaptująca narzędzia sztuki animacja kultury na różne sposoby usiłują działać w kierunku wywoływania zmiany społecznej, punkt wyjścia działań to tylko początek, potem pojawić się już maja „punkty końcowe”, nowa zmieniona sytuacja społeczna, kulturalna, polityczna. Oczywiście można pokazać, że jest to strumień mający liczne odnogi - począwszy od prac artystów tworzących w projektach collaborative art (zob. np. Binder 2005) czy community arts (Crehan 2008; Ptak 2008, Rogozińska 2009), w których na przykład pojawia się projekt opisu i twórczego przenikania się perspektyw artystów i badaczy społecznych. Być może zatem to tego typu polityka społeczna chce przede wszystkim budować nowe formy i standardy współbycia ludzi, nowe - czyli elementy „sztucznie wywoływane", wprowadzane z zewnątrz.

Podobnie jednak nauki społeczne w dużym stopniu już dawno odeszły w różny sposób od swej dawnej pozycji beznamiętnego obserwatora zjawisk i coraz intensywniej wchłaniają narzędzia sztuki i buduja w ten sposób wiedzę zaangażowana społecznie czy politycznie. Od kilkunastu lat powstają nowe prace, na przykład Between Art and Anthropology. Contemporary Ethnographic Practice (Wright; Schneider 2010) czy Contemporary Art and Antbropology (Wright; Schneider 2005), gdzie analizowane są pokrewieństwa i połączenia obu typów wrażliwości i praktyki interpretacyjnej. Powstaja prace zakreślające możliwości adaptowania narzędzi sztuki w badaniach społecznych, takie jak Method Meets Art. Art-Based Research Practice (Leavy 2009) czy wprowadzające nowe sposoby myślenia o antropologii i sztuce w obrębie polityki produkcji kulturalnej Anthropology, Art and Cultural 
Production (Svašek 2007). Warto tu jednak może wskazać na dość dawno rozpoczętą tradycję myślenia zaangażowanego, łącząca antropologie postmarksistowskie z praktykami zaangażowania społecznego przez różne typy działań, m.in. działań artystycznych. Na poziomie bardziej przyziemnym i metodologicznym przywołać więc trzeba dawny projekt Lisy Sola Taxa (2010), prowadzony wśród zubożałych i zrezygnowanych Indian Meskwaki - ustanowił on pewien punkt zerowy nowego typu badań społecznych, który stopniowo nabierał charakteru społecznej i politycznej walki o poprawę ich bieżącej sytuacji i pozycji w strukturze. Były to narodziny pewnej nowej sytuacji nie tylko społecznej, ale i poznawczej, okazało się bowiem, że efektem projektu były nie tylko działania, ale jednocześnie zupełnie nowa, powstająca „w ogniu walki” wiedza - narodziła się świadomość czegoś takiego jak ,akcja badawcza” „badania w działaniu” (zob. Badania $w$ driałaniu...). W kolejnych odsłonach tego typu projektów powstawała cała nowa struktura wiedzy społecznej, wiedzy o zjawiskach jednocześnie obserwowanych i wywoływanych - o zjawiskach nieobojętnych autorom badań. Metodologowie, tacy jak Wilfred Carr (2010), będa pokazywali, że być może to znacznie bardziej naturalna sytuacja poznawcza - pewna hermeneutyka akcji i bieżącego działania, nieustannego testowania i odkształcania wiedzy niźli pozycja dystansu i wyłączenia (pozycja skole, jak to określił Pierre Bourdieu, a więc funkcjonowanie w ramach pewnej swobody czasu i bezpiecznego dystansu do opisywanych wydarzeń).

Ponad 40 lat później, po coraz bardziej zaawansowanych próbach action research, wewnątrz nauki społecznej dokonuje się jednak coś znacznie bardziej radykalnego - nauka zaangażowana odkrywa swą niemoc, swe wyczerpanie. Amerykańska antropolog, Nancy Scheper-Hughes (2010), która prowadzi od wielu lat badania wśród głodujących mieszkańców faveli w miastach północno-wschodniej Brazylii, w zdeindustrializowanych miastach (byłych centrach przetwarzania trzciny cukrowej), uznaje, że w tych warunkach, w sytuacji bycia z ludźmi faveli, tradycyjna praca nad gromadzeniem materiału zaczyna być czymś mocno niestosownym. Po latach badań coś się w jej pracy gwałtownie zmienia: po jednym z wydarzeń, kiedy opuściła na kilka godzin jedna z bliskich jej rodzin, aby uczestniczyć w ważnym poznawczo wydarzeniu, w trakcie jej nieobecności zmarło jedno z dzieci, pozbawione opieki medycznej, niedożywione. Antropolog od tego momentu, wykorzystując swą wiedzę, podejmuje intensywne działania, zaczyna budować wiedzę politycznie skuteczna, wstrząsająca, ,wojująca”" (militant). Jej interpretacje zamieniają się w krzyk wobec niesprawiedliwości i nierówności wśród ludzi. Jej antropologia, oskarżana o nadinterpretacje 
i manipulowanie kontekstem, staje się w ten sposób aktem sprzeciwu, wiedza, jak sama pisze, bosonogiego uczonego (barefoot anthropologist) uczonego, któremu nic już nie zapewni bezpiecznego dystansu od tego, co najbardziej bolesne w doświadczeniach społecznych.

\section{/// Nauki społecznie zaangażowane}

Hal Foster, krytyk i teoretyk pochłonięty pozycjonowaniem sztuki współczesnej, w swojej pracy Powrót Realnego. Awangarda u schytku XX wieku (2012) pokazuje, że takie spotkanie zaangażowanej nauki społecznej i aktywistycznej sztuki jest, być może, pewną prawidłowością. Pokazuje, że aktywizm artysty może jakby powtarzać drogi dwudziestowiecznej antropologii, czyli sprofesjonalizowanego studium obcości i, podobnie jak to przestawiał Walter Benjamin, może wydobywać się z marksistowskiej roli artysty - twórcy nowych stosunków społecznych, artysty wypromieniowującego z siebie nowy podmiot - świadomy, walczący proletariat. To, czego zatem potrzebuje artysta, pisze Foster, to wyjście na zewnątrz w stronę nie swoich doświadczeń, w stronę odmiennego i peryferyjnego świata społecznego, aby tam znajdować moce buntu, oporu i subwersji. Tak pojawia się idea wyjścia do światów spoza mainstreamu kulturalnego, w których działanie artysty nabiera ciężkości, a artysta, niczym rzemieślnik-rewolucjonista, niczym radzieccy konstruktywiści, z filmowcem Dżiga Vertowem na czele, „montuje” nowe społeczeństwo (zob. Marcus 1995: 106) - sięga po materię nowych aktywności, wypartych głęboko z miejskiego, kapitalistycznego, centralnego świata. Artysta, pokazuje Foster, działa w ten sposób trochę niczym etnograf - działa bowiem wśród tego co inne, obce kulturowo, a pierwotnie skolonizowane. Działa więc także wśród doświadczeń grup podporządkowanych i wykluczonych, w miejscach społecznych napięć, doświadczając wyobcowania i egzotyzacji siebie samego (self-othering). Podobnie jak surrealiści i etnografowie $z$ lat dwudziestych i trzydziestych XX wieku prymitywiści i poszukiwacze realizmu życia usiłują dotrzeć w miejsce kulturowych peryferii, a stamtąd pozwolić spojrzeć w oczy obiegom dominującym, „galeriom”, „publicystom”, „nauczycielom” - i zmusić tym samym zachodnie, dostatnie społeczeństwa do spojrzenia w oczy samym sobie. Być może jest to zatem spojrzenie chwilowe, pośrednie, być może to nawet pewien instytucjonalno-polityczny koniunkturalizm, próba nadążania za kolejnym centralnym, porywającym strumieniem uwierzytelniającym po prosu sztukę - sztukę par excellance. Sztukę, która aby żyć, musi być społeczna. 
Jak w obliczu tych obciążeń w ogóle działać przez sztukę? „Co robić?”. Czy zatem cała tradycja community arts, zmiany wewnątrz sztuki krytycznej, nowe poszukiwania w obrębie nauk społecznych i antropologii maja w ogóle szansę na rozwój? Warto zdać sobie sprawę, że działania artystyczne wśród społeczności niosą ze sobą pewne odium spontanicznej, oczywistej krytyki, w duchu Hala Fostera. Projekty animacyjno-artystyczne się „nie udaja” - tak jak można znaleźć wiele opisów nieudanych projektów rozwojowych (zob. Mosse 2006), w których wskazuje się na to, że absurdem jest budowanie studni w tym akurat miejscu - tak można znaleźć wiele opisów akcentujących porażki animacji kultury i działań artystycznych skutkujących dalszym, obustronnym wyobcowaniem ludzi (zob. m.in. Kwiatkowska 2007, Określenie formuly instytucjonalnego wsparcia oddolnej ak.tywności kulturalnej... 2012: 69-87). Działania przez sztukę w środowiskach peryferyjnych w sposób regularny spotykają się z krytyką, wręcz karykaturalizacją i zarzutami „niesienia kultury”, „poprawiania”, „,edukowania” czy nawet „zmuszania do wspólnej pracy-zabawy”. Powtarzalność tych sądów wiąże się na ogół z tym, że często wydaje się, iż skutkuje ponownym uznaniem tych ludzi za w pewien sposób niedoskonałych, „,niepełnych”. To być może wtedy dokonuje się właśnie nie tyle „praca pozytywna”, ile „podwójna kolonizacja” (Gandhi 2008: 81) - wpasowywani „odbiorcy” projektów $\mathrm{w}$ rolę postaci stereotypowych, niepełnych, ubogich twórczo. Zarzuty wobec idei działań animacyjnych, wobec prowadzenia działań artystycznych - czy to na rzecz innych, czy z innymi - można zatem uznać nie tylko za pewne profesjonalne, humanistyczne osądy, ale też za „fakty społeczne", a więc świadectwo pewnej formy wyobraźni społecznej, jaką właśnie teraz dysponujemy. Szczególnie osoby nastawione na etnograficzne rozpoznawanie zniuansowanej, pełnoprawnej, oddolnej kultury moga mieć wrażenie, że przychodzenie z zewnątrz z projektami kulturalnymi to rodzaj nadużycia, przemocy, ,zmiany na siłę”. Sam zreszta pamiętam swoje odruchowe myśli - biegły niegdyś bardzo podobne.

\section{/// „Co robić?”}

Jak zatem działać? Czy można w ogóle używać sztuki, wprowadzać jej elementy do życia swojego i innych, nie budując jednocześnie gdzieś, w tyle głowy, pozycji wyższości i dominacji? Czy można jej tak używać, by nie wytwarzać sytuacji „zmuszania do udziału”? Od kilku lat próbujemy na to pytanie odpowiedzieć wraz z całym zespołem animatorów, artystów i etnografów. Od jakiegoś czasu prowadzimy projekt animacyjny 
w dwóch wioskach w okolicach Szydłowca - Ostałówku i Broniowie. Sa to miejsca dotknięte na dużą skalę nieopłacalnością drobnego rolnictwa i niekończącym się, lokalnym bezrobociem. To miejsca, gdzie praca jest znajdowana głównie za granicą albo na budowach dużych miast; miejsca, gdzie wahadłowe migracje zarobkowe, wyjazdy i powroty wypełniają codzienność, a praca jest niemal zawsze doraźna, tylko chwilowa. To wsie niegdyś rolnicze, liczące około stu „numerów” (gospodarstw). W jednej ostało się ledwie kilka czynnych gospodarstw, w drugiej jest ich znacznie więcej, choć są drobne, karłowate - często tak małe, aby w razie czego móc otrzymać świadczenia społeczne.

We wsiach tych prowadzimy od 2005 roku etnograficzne badania terenowe - mieszkamy i przebywamy z ludźmi, zdobywając coraz głębszą i coraz bardziej nieoczywistą wiedzę o ich codzienności, ukrytych potrzebach i pragnieniach. To dopiero po tego typu doświadczeniach zostały przygotowane i poprowadzone $\mathrm{w}$ kolejnych latach projekty artystyczne, w których wiedza etnograficzna przeradzała się w działania animacyjne. Sądzimy, że etnografia w połączeniu z działaniami animacyjnymi stwarza warunki, by ujawniło się to, co bardzo istotne w życiu tych społeczności - może wzbudzić niejawny wymiar ich twórczego działania i ich własnej, oddolnej samoorganizacji. Projekt, który tu przedstawiam, to Prolog. Nierozpoznane wymiary rozwoju kulturalnego z roku 2011, a następnie jego rozwinięcie Etnografia/Animacja/Sz̨tuka z 2012 roku. To w najprostszym znaczeniu kontynuacja tej raz zadzierzgniętej więzi, opowieść o tym, jak poznanie etnograficzne i pewna bliskość przeradzały się później w coś, co nazwać by można działaniem w kulturze.

Po pierwsze, jest to etnografia, przebywanie wewnattrz spotkań i wydarzeń, umiejętność uchwycenia niezwykłego, „gęstego" świata życia we wsi. Po drugie, to animacja, tworzenie projektów i wszelkich sytuacji, w których następuje wspólne działanie, tworzenie. Po trzecie, to sqtuka, forma sztuki w starym znaczeniu, aktywności cielesno-imaginacyjnej, zgodnie z praindoeuropejskim rdzeniem ar-, a więc sztuki jako działania - społecznego, jednostkowego, widowiskowego. To ciag spotkań, budujących nowe znaczenia, odwracających i przebudowujących symbole, przemieniających relacje społeczne. 
O ile można przyjać, że animator posługuje się narzędziami sztuki, to nie tworzy on „dzieła dla ludzi, lecz z nimi”, a więc przed wszystkim „pracuje z innymi, nawiązuje relacje, tworzy sytuacje" (Reksnis bd). W tym wypadku powstawało dzieło - były nim chociażby sytuacja, spotkanie, które działały, zmieniały tak „ich”, jak i „nas”, tak adresatów, jak i inicjatorów wydarzeń. W czasie projektu wszyscy doświadczamy życia z ludźmi ${ }^{1}$, przebywania z nimi, mieszkania; bierzemy udział w doświadczeniach etnografii i swymi działaniami próbujemy powołać ruchy animacyjne. Drobiazgowa, etnograficzna wiedza o lokalnym świecie, o wiejskich grupach, o ich aktywności rodzi animację kultury. Animacja kultury (Animacja Kultury 2002, Lokalnie... 2008, Terą! Animacja kultury bd.) za pomoca narzędzi sztuki tworzy warunki do wspólnej twórczości - do spotkań, rozmów, wzajemnego zaangażowania. Sztuka, szczególnie sztuka współczesna, wprowadza natomiast, jakby z trzeciej strony, swoją odmienna, odważna, czasem wręcz prowokująca wizję akcji artystycznej, pewien zewnętrzny typ wyobraźni, nasycając działania czymś w rodzaju niepokornego, krytycznego źródła (czy nawet logiką „łagodnej przewrotności”, by użyć sformułowania Elżbiety Jabłońskiej).

Jak taki projekt działa? Jest kilka płaszczyzn, kilka przenikających się rzeczywistości tego, co się wydarza. Po pierwsze, wydobywa się to, co w tych społecznościach ukryte, wartościowe, co silnie związane z lokalnym, odkrywanym dopiero wyposażeniem kulturowym, i co jednocześnie tworzy pole dla wspólnej wyobraźni. Po drugie jednak, pojawia się tam przede wszystkim moment powstawania czegoś nowego, jakby elementy trzeciej logiki, ani kulturowej, lokalnej, ani zewnętrznej (projektowej). Przedstawię tu rozbudowany opis takiego projektu, jednego z kilkunastu, które prowadziliśmy, ale odsłaniającego, w moim przekonaniu, właśnie to przechodzenie jednego procesu w drugi i wydobywanie pewnych nowych treści.

\footnotetext{
${ }^{1}$ Zespół „przybyszów” pracujący w Broniowie i Ostałówku to zatem zarazem etnografowie, animatorzy kultury, jak i artyści-twórcy. Razem niemal dwadzieścia osób. Etnografią zajmują się na co dzień Pola Rożek, Ewa Chomicka, Maja Dobiasz, Piotr Cichocki, Tomasz Rakowski - choć wszyscy tworzyli jednocześnie w tym projekcie działania artystyczno-animacyjne. Działaniami artystyczno-animacyjnymi trudnią się Aleksandar Ćirlić, Agnieszka Pajączkowska, Agata Pietrzyk, Zuzanna Naruszewicz, Dorota Ogrodzka, Julia Biczysko, Sebastian Świąder, Paweł Ogrodzki, Piotr Bielski - choć wszyscy są doświadczonymi badaczami, twórcami badań społecznych i etnograficznych. Artyści, ludzie ze świata sztuki współczesnej, to Elżbieta Jabłońska, Łukasz Skąpski, Wojtek Ziemilski, Agata Bielska; w projekcie biorą też udział opowiadacz Jarek Kaczmarek i multiinstrumentalista Gwidon Cybulski. Choć dla większości z nich etnograficzne mieszkanie i przebywanie z ludźmi było czymś nowym, to jednak mają własne życiowe, biograficzne doświadczenia bycia i działania na wsi.
} 


\section{/// Opisywanie metody: projekt „Urządzenia z Broniowa i Osta- łówka"}

W projekcie poświęconym urządzeniom z Broniowa i Ostałówka pracujemy w kilka osób ${ }^{2}$. Wraz z artystą Lukaszem Skąpskim, członkiem krytyczno-interwencyjnej grupy Azorro, poznajemy świat wiejskiego przerabiania maszyn i urządzeń, świat, o którym dużo już wiemy, ale teraz dopiero odkrywamy go o wiele bardziej intensywnie, poznajemy po kolei ludzi, którzy sami wykonali swoje urządzenia, drabiny, spawarki, kosiarki z silnikiem z pralki „Frania”, szatkownice, nawet siłownie i urządzenia do ćwiczeń. Stopniowo zaczynamy wzbudzać zaciekawienie naszym zainteresowaniem tą sferą: ludzie odsyłaja nas do sąsiadów, pokazują niezwykłe ciagniki własnego pomysłu typu „SAM”, samoróbki, „papaje”. Oglądamy skonstruowany przez młodych samochód, gokart, jak sami mówią, z pospawanych rurek, na ramie zrobionej ze starych grzejników, z silnikiem i deska „,malucha”, grillem peugeota. Z młodymi mężczyznami, zajmującymi się szrotowaniem i przerabianiem samochodów, spotykaliśmy się chyba najczęściej - mają w Broniowe pięknie wyeksponowany szrot (kasacje), na zakręcie, koło chałupki oplecionej winorośla. Kiedy tam przychodzimy, chłopcy rozkuwaja właśnie starego poloneza pick-upa, po wydostaniu „serca”, silnika pojazdu (na sprzedaż, reszta na pojedyncze części i na złom), opowiadają o ich dawnym, czerwonym fordzie taunusie, do którego wstawili potężny, oplowski silnik i zimą jeździli z butlami gazu (do oporu, wściekali sie), zmieniali w jeździe butle $\mathrm{z}$ gazem. Stopniowo odsłaniamy obecność maszyn i zaczynamy ją dostrzegać niemal wszędzie. Odkrywam na przykład, że trzy pilarki zgromadzone przez gospodarza z Ostałówka jego syn zrobił z czterech innych, przerzucając pomiędzy nimi części, świece, prowadnice, tak aby cięły jak najlepiej. Zaczynam dostrzegać samochody, w nocy mają widoczne neoniki pod szybami, w reflektorach, niebieskie światła mijania, malowane barwnie zaciski hamulcowe (w Ostałówku widzę, jak wieczorem pod świetlicę z okolicznych wiosek podjeżdżaja przemalowywane i przerabiane na wiele sposobów samochody młodych, z ich specyficzną estetyką świateł, neoników, opon, felg, zacisków hamulcowych). Odkrywamy wspólnie, że jeden z mieszkańców, kolejarz, murarz, konstruktor, przyspawał naftowe lampy kolejowe do bramy swojej posesji, a jego syn z lamp semaforowych robi kolorofony oraz że skonstruował niezwykłe wyposażenie swego skutera - jego podświetlone na niebiesko podwozie reaguje na głos, dźwięk, mruga zgodnie z nimi.

\footnotetext{
${ }^{2}$ Lukasz Skąpski, Maja Dobiasz, Zuzanna Naruszewicz, Ewa Chomicka, Tomasz Rakowski.
} 
To pewna zagęszczająca się wiedza etnograficzna. Tak naprawdę jednak dzieje się coś więcej. Artysta Łukasz Skąpski dokumentuje te rzeczy, nagrywa filmy, rozmawia. Robi sesje zdjęciowe młodym w ich siłowniach, w łagodnym świetle, z rekwizytami - odważnikami w rękach, nagrywa film pt. Fitness oraz film dokumentujący maszyny samoróbki, czyli Urz̨qdzenia zBroniowa i Ostatówka. Te nagrania i dokumentacje wypływaja jednak przede wszystkim ze spotkań i wzajemnego zainteresowania; to one wydobywaja z tego miejsca filmy, zdjęcia, działania. A więc od początku - zaczyna się tu, coraz bardziej wartko toczący się, strumień doświadczeń ze spotkań z ludźmi - w ich gospodarstwach, warsztatach. Te spotkania sa początkowo niepewne, chwiejne, zbudowanie relacji z ludźmi jest trudne. Swoje przeróbki i urządzenia wytwórcy moga widzieć wprawdzie jako coś „własnego", z czego sami przed sobą są w pewien sposób dumni, ale w relacji $z$ artysta moga przecież widzieć, i widzą, że jest tu coś niepewnego, coś, czego trochę się wstydza, a trochę obawiają są to w końcu nierejestrowane, sobie-robione maszyny, traktory, wbrew regulacjom, wbrew zestandaryzowanym technikom i technologiom. To świat cichego, ukrywanego radzenia sobie z potrzebami codzienności i wreszcie - wioskowego obniżania kosztów życia.

Pracuje nas, jak wspomniałem, kilka osób, wspólnie przygotowujemy jakby wstępną przestrzeń dla pracy Lukasza. Wspólne rozmowy, przeglądanie z chłopkami ze szrotu albumu Lukasza Maszyny (2009) powoduja, że miejscowi zaczynają coraz bardziej rozumieć tę naszą fascynację tym, co oni robią, my zaś zaczynamy widzieć to wszystko inaczej. Kiedy nagle odsłaniaja ukryte pod plandekami, tuż obok nas, najlepsze, wymontowane silniki, BMW 2000, Seat DOHC 16V, VW GTI 1800 - widzimy, że to zasobniki tego, „co najlepsze”. Zaczynamy nieśmiało mówić o pomyśle na nocną wystawę silników i urządzeń. Rzecz w danym momencie tu, na miejscu - na razie niewyobrażalna. Od tej chwili zaczyna się jednak spotkanie pomiędzy naszą (moja) a ich wrażliwością, między „nami” a „nimi”. Nie tylko dostrzegamy obecność robionych własnoręcznie urządzeń, ale zaczynamy nimi działać, przesuwać je w inny kontekst - coś chcemy razem z nimi robić, a wszystko się obraca wokół ich wiedzy, umiejętności i wyobraźni technicznej. Wtedy też jeden z mechaników - Andrzej Chylicki - zaczyna myśleć o uruchomieniu gokarta, o co zresztą kilkakrotnie prosimy. Obiecuje przyjechać swoim podrasowanym, czarnym oplem, z niebieskimi neonikami, srebrnymi felgami i żółtymi zaciskami hamulcowymi pod świetlicę, na koncert i opowieści bluesowe Jarka Kaczmarka. Wieczorem, w ciemności, podjeżdża swym wozem pod schody świetlicy, 
co rozpoczyna opowieść Kaczmarka o bluesmanie, jadącym cadillakiem daleko, w trasę do Ameryki. W następnych dniach coraz więcej ludzi odsłania przed kamerami i aparatami swoje urządzenia, a Lukasz coraz więcej odkrywa ludzi dumnych ze swojej maszyny - ze swojej roboty (pierwsze, co słyszymy, to oświadczenie, ile nawoziła/naspawała/naciąnęła/nacięła dana maszyna, jak jest wydajna). Kilka tygodni później, na finale tego projektu, wszystkie te maszyny ludzie przywoża, przepychają pod świetlicę wiejska, powstaje zgromadzenie i wystawa. Lukasz Skapski opatruje eksponaty starannym opisem - specyfikacją rodem ze świata sztuki wystawienniczej. Dzieje się jednak znów coś więcej - wszyscy się przyglądaja, od nowa dostrzegają swoje maszyny, u siebie i u sąsiadów. Co chwila ktoś odkrywa wtedy i obwieszcza, że ma przecież jeszcze wiele takich sprzętów: grabie, przyczepkę, że jeszcze to przyniesie, przyciagnie, ustawi. Maszyny wchodzą na wystawę „tego, co najlepsze”. Do ostatniej chwili ludzie się wahaja; Andrzej Chylicki do samego końca nie był pewien, czy jego gokart powinien tam się pojawić. Kiedy do niego przychodzimy, okazuje się, że oczyścił silnik, filtry, zatankował, a z linki hamulca ręcznego właśnie skręca linkę gazu - bez tego przejazd autem byłby niemożliwy, po prostu by się nie odbył.

Ta specyficzna kultura przeróbki przestaje być w ten sposób jakimś „odkryciem”, jakimś „wycinkiem kultury”. Dokonuje się bowiem jej nieoczywiste uruchomienie, aktualizacja, jakby porozumienie wokół tego, co na naszych oczach - i dla nas, i dla mieszkańców - staje się nowym doświadczeniem. Narzędzia, ich różnorodność i nieprzeciętność (wykaszarka z silniczkiem od czeskiego młynka do kawy), stają się w ten sposób nie tylko jakąś rzeczywistością, ale rzeczywistością, która tkwi bezustannie w głowach nas wszystkich; ludzi z Broniowa, Ostałówka, nas, artysty Łukasza - to coś, co wspólnie wytwarzamy. Młodzi malują sprejami z projektu części hamulcowe, dzieci - koła swoich rowerów. Kiedy kilka tygodni później kosiarka pana Wiesława trafia na kubik wystawowy w warszawskiej Kordegardzie - rozgrywa się tam listopadowy finał projektu - jest podświetlona, oznakowana specyfikacją obiektu galeryjnego.

\section{/// Wydobywanie metody (1): Kulturowy cyklotron}

Co jest najbardziej charakterystyczne dla tego typu działań? Ta artystyczno-animacyjna obecność zakorzeniona jest tu przede wszystkim w zaangażowanych, etnograficznych badaniach oraz w doświadczeniach spotkania etnograficznego, w rozpoznaniu ,gorących” miejsc kultury (takich 
jak owe praktyki przerabiania i wytwarzania urządzeń). Społeczne życie ludzi, pamięci, przedmiotów czy inwencji, całe te „przesłonięte działania" zostaja jakby ponownie wywołane. W ten sposób granica między aktami poznania (etnografia) i działania (animacja) staje się, rzekłbym, „półprzepuszczalna”, działa w obydwie strony - etnografia przez działania animacyjne, „odgrywające kulturę”, staje się bardziej intensywna (fakty etnograficzne powstaja razem z działaniem w niezwykle intensywny, ale i zmieniony sposób), a sama animacja, przez swe etnograficznie ukorzenienie, sięga do najbardziej subtelnych doświadczeń kulturowych. Po pierwsze więc charakterystyczne jest zanurzenie tego procesu w samej rzeczywistości społecznej. Po drugie jednak, co może nawet bardziej już teraz istotne $-\mathrm{w}$ uruchomieniu często ryzykownych i nieprzewidywalnych działań, pobudzających i uruchamiających wielorakie sfery kultury.

Efektem, produktem tego procesu nie jest zatem samo „dzieło”, lecz w tym wypadku raczej zwielokrotniona gęstość wydarzającej się interakcji - „kultury w działaniu”. To przekroczenie granic pomiędzy tym, co etnograficzne, i tym, co animacyjne, związane jest w ten sposób szczególnie z koncepcja „zwrotu działaniowego" w naukach społecznych (Carr 2010) i idea etnografii performatywnej - „pobudzania i odgrywania kultury” (Alexander 2009). Powstaja zatem warunki działania, które przeciwstawiają się wizji kultury jako z góry zdefiniowanych zasobów - w których coś, co się wydarza, choć zanurzone w lokalnym świecie kulturowym, jest zawsze czymś nowo powstającym i aktualnym, pojawiaja się nowe miejsca spotkania. To kreowanie, można by rzec, nowego, partycypacyjnego świata „epistemologii poszerzonej” (Reason, Torbet 2010) - gęstość etnograficznej wiedzy zasila tu działania artystyczno-animacyjne i jednocześnie jest na odwrót: działania tworzą warunki, wytwarzają środowisko kultury i jej etnograficzne bogactwo. Te dwie zasilające się nawzajem sfery aktywności przyjmują więc strukturę swoistego cyklotronu, w którym każda z nich rozpędza krążenie cząstek aktywności - odsłania nierozpoznane i pozostające w stanie potencjalności działania w kulturze. W projektach, w trakcie działań artystycznych pojawiaja się w ten sposób wydarzenia, zwroty akcji, sytuacje etnograficzne, w których to, co zwiemy czymś „,kulturowym”, istnieje jakby intensywniej, bardziej nieprzewidywalnie i spontanicznie, istnieje za każdym razem na nowo, nieco zmienione, ,sztucznie” wywołane - pojawia się więc za każdym razem nieco „nowy” świat. 


\section{/// Wydobywanie metody (2): spotkania, widowiska, sytuacje et- nograficzne}

Taka etnografia i zarazem animacja wydarzeń wiąże się mocno z wizja praktykowania swoistej antropologii widowisk. Na przykład Victor Turner, wychowany w rygorze brytyjskiej szkoły antropologii, nie mógł zrozumieć, jak można zamykać doświadczenia społeczne - doświadczenia współbycia, współdziałania z ludźmi - w notatkach, schematach graficznych, wywiadach, w unieruchomionym materiale badawczym. Taka antropologia - pisał Turner - jest co najmniej mało atrakcyjna - badacze kultury długie godziny spędzaja nad spisywanymi relacjami, tak jakby z góry zakładano, że analiza „dotyczy trupa”. Tymczasem - jak pisze za D.H. Lawrence'em - powinna ona stawiać w centrum uwagi „żywego mężczyznę” i „żywą kobietę”. „Doszedłem do wniosku - twierdził więc Turner - że czytanie i komentowanie materiałów etnograficznych to za mało; tak naprawdę powinniśmy je odgrywać" (Turner 2005: 147). O ile zatem Turner postuluje ożywianie martwego tekstu etnografii przez jej odgrywanie po to, aby „,wpleść czytelników i widzów w kulturową sieć motywacyjną" (tamże: 148, 164), o tyle w naszym projekcie to zadanie plasuje się jeszcze wcześniej, w praktyce etnografii, jej kontynuacji. Etnografia staje się więc tutaj etnograficznym performansem, zgodnie $z$ etymologia słowa performance, wskazanym przez Turnera, które oznacza „ukończyć”, „w pełni wprowadzić w życie" (tamże: 17).

Projekt działania animacyjnego staje się w ten sposób wręcz naturalną konsekwencją badań terenowych. „Przedstawić etnografię - pisze zatem Turner - to wykorzystać zebrane dane terenowe w ich pełni działaniowoznaczeniowej” (tamże: 151). Co to oznacza? Otóż w ten sposób, można by rzec, badania już od początku przemieniają się w coś zupełnie nowego - w coś w rodzaju dramatu etnograficznego, owej pełni „działaniowoznaczeniowej", w której powstaje dopiero pole dla najważniejszych procesów twórczych. Zamiast badania jest spotkanie, zamiast obserwacji uczestniczącej - działanie (,wykonywanie”, performans), zamiast kierunku badawczego i przedmiotu badania - sytuacja etnograficzna i gęstość interakcji. To chwila, na przykład, w której rozmawiamy (wraz z Zuzanną Naruszewicz) z młodym mechanikiem szrotowcem, Andrzejem Chylickim, kucającym na zmontowanej ze starych szkolnych grzejników ramie gokarta; Andrzej skręca na nowo linkę gazu z linki hamulca ręcznego (musi być teraz cieńsza), chce uruchomić „dla nas” pojazd, na wystawę. Robi to, co już robił, wymyśla działanie techniczne, ale w naszej obecności ma to już inny sens, robi coś, co jest na nowo mu potrzebne. Sens tej przeróbki, 
z jednej strony, przestaje być oczywisty, z drugiej, jest już doświadczeniem nowym, wspólnym - każdy na swój sposób odpamiętuje wspomnienia o samochodach przeróbkach, o jego fordzie taunusie, którym wściekali sie po polach, o trzystu autach, które z bratem, jeszcze kiedy chodził do szkół, rozebrał, których, jak mówił, nie spamięta. Jednak i my widzimy to wszystko inaczej, wchodzimy do innego świata, o którym wiedzieliśmy, że jest, ale teraz on ożywa przed nami i wokół nas, widzimy nie tylko wiejskie, spontaniczne prace młodych przy maszynach, ale i to, co można zrobić: wspólną paradę, przejazd gokartem, pokaz jego wiraży. Te nowe wyobrażenia wydobywaja się i wybuchają po dwóch stronach - naszej i jego, mieszkańca Broniowa. To spotkanie - sytuacja etnograficzna, nowe pole współuczestniczenia, w którym przetwarzana „,wiedza” powstaje po stronie Andrzeja, ale symetrycznie także po stronie etnografów-animatorów, którzy zaczynają nią też na swój sposób żyć. Pomiędzy tym, co należy do „terenu”, „wiedzy kulturowej”, a wiedza badaczy-animatorów zaczyna zatem pojawiać się przepływ, zmienia się formuła etnografii. Etnograf-animator przestaje być w ten sposób ośrodkiem rozumienia - wchodzi raczej do wewnątrz pola kulturowego i sam jest częścią wydarzeń kulturowych, estetycznych, technicznych, społecznych, tworzy scenę kulturowego zjawiska. To jakby decentracja pola badawczego - i mieszkańcy, i badacze-animatorzy wspólnie wytwarzająprzedmiotbadań,zanimpodążaja. Etnografanimator wchodzi do niego nieco z boku, wślizguje się w jego obręb, staje się „etnografem” lub ,animatorem” w trzeciej osobie - sam dla siebie staje się częścią procesu, który wybucha, rozwija się i który et-nograf-animator naraz obserwuje i opisuje. To sytuacja, którą kilkakrotnie przywoływała Kirsten Hastrup (2006; 1998), opisując siebie jako postać „etnografki” - jako swą sobowtórkę („nie-nie ja”) w polu wydarzeń. Sam badacz, etnograf czy artysta wchodzi wówczas do wewnątrz pola, staje się częścią badanego czy wywoływanego zjawiska.

To jednak także chwila, gdy wydarza się coś szczególnie ważnego. Kiedy powstaje sytuacja spotkania - Lukasza Skapskiego i Mai Dobiasz z ludźmi od urządzeń - dwie strony przez chwilę istnieją jakby inaczej, na nowo, niezwykle intensywnie. Takie spotkania są rzadkie; to jakby punkty krańcowe długiego podskórnego procesu działania, doprowadzającego w końcu do sytuacji, w której dwie strony wydostają się poza swe dotychczasowe sposoby istnienia, kiedy biora zarazem udział w zagęszczonej rzeczywistości kultury. Podobnie jak w etnograficznym teatrze eksperymentalnym (spektakl Talabot Eugenia Barby z udziałem Kirsten Hastrup, eksperymenty Richarda Schechnera i Victora Turnera), gdzie nastapić może owo „ryzykowne 
przywrócenie doświadczenia”, w którym przeżycia biorących udział w spotkaniu (spotkaniu - widowisku - sytuacji etnograficznej) zostaja, jak za Diltheyem pokazywał Turner, „wyciśnięte”. Dokonuje się tu przemiana w tym sensie, że jesteśmy (animatorzy/badacze/artyści z jednej i ludzie miejscowi z drugiej strony) wspólnie, przez chwilę, trochę „innymi ludźmi”. Patrzymy na siebie „z ukosa”, nie w pełni się rozpoznając, ale, jednocześnie, odkrywając siebie na nowo (,rodzę się, abyś się urodził” każda ze stron zdaje się mówić, by przywołać metafory Jerzego Grotowskiego, 1972: 51). To chyba najtrudniej opisywalny efekt tych działań - sa to jakby zagęszczające wydarzenia, sytuacje etnograficzne i artystyczno-animacyjne, sytuacje „międzyludzkie”, których cechą charakterystyczną jest to, że sa poboczne, w dużym stopniu nieprzewidywalne. To pewne punkty krańcowe, punkty dojścia, na które długo pracuje cała dynamika projektu; jednocześnie taki moment to tylko zdarzenie na linii prowadzącej do finału, ale to chyba zarazem najbardziej niezwykłe i potrzebne wydarzenie - to chwila porozumienia, poczucia, że naraz myślimy inaczej niż zwykle, że razem stajemy się kimś innym niż zazwyczaj. Albo że jesteśmy „tacy sami” - w każdym z nas zachodzi przecież w tym czasie przemiana.

\section{/// Dekolonizowanie metody}

Powróćmy jednak do początku. Projekt Prolog. Nierozpoznane wymiary rozwoju kulturalnego i jego kontynuacja Etnografia/Animacja/Sztuka miały na celu zbudowanie nowej perspektywy poznawczej i animacyjnej - perspektywy, która będzie w stanie odwrócić i zdekolonizować dyskurs „lokalnego rozwoju"; będzie w stanie odwrócić wszelkie praktyki instytucjonalne, narzucające już a priori wizję ,właściwej” kultury i właściwie ukierunkowanego „rozwoju kulturalnego”. Nie ma co ukrywać, że mierzymy się w ten sposób z wyobraźnią społeczną, dotyczącą współczesnej wsi polskiej, przedstawiająca jej mieszkańców, ich życie społeczne, aktywność kulturalną jako niepełne, zapóźnione, wymagające edukacji i programu naprawczego. W wielu debatach i różnego typu dyskursach publicznych życie to przedstawia się bowiem za pomocą obrazów bylejakości i monotonnej codzienności, wolno płynącego czasu i braku dostępu do jakiejkolwiek wartościowej kultury ${ }^{3}$. Są to rozpoznania, które najczęściej już na wstępie odmawiaja tym społecznościom zdolności do własnego, wartościowego sposobu działania, do odnowy i modernizacji według własnych wzorów

\footnotetext{
${ }^{3}$ Przykładami są film dokumentalny Czelkajac na sobote (2010) czy niektóre głosy z debaty prowadzonej wokół chłopskiej genealogii polskiego społeczeństwa w miesięczniku „Znak” i w „Gazecie Wyborczej” (zob. Wasilewski 2012).
} 
i własnych potrzeb. W bardzo różnych miejscach można napotkać narracje naukowe i publicystyczne, jednostronnie wypełnione wizja kultury wsi jako „balastu”, jako czegoś, co przekreśla powstawanie „właściwej” klasy średniej i „właściwego” społeczeństwa obywatelskiego. Tymczasem problem polega na tym, że ludzie ze środowisk peryferyjnych, wiejskich czy w ogóle - niecentralnych - bardzo aktywnie działaja, „wytwarzają kulturę”, praktykuja ją na własny sposób, też w tym sensie, że nigdy nie przestaja, że człowiek w każdych warunkach działa, wytwarza, przestawia, „nothing - można by powtórzyć za Ervingiem Goffmanem - never happens” (zob. Mencwel 2006: 79). Dzieje się to jednak najczęściej w innej warstwie, w niewidocznych miejscach kultury - w nierozpoznanych wymiarach potrzeb kulturalnych i rozwoju kulturalnego. Ekspresja kulturowa może tam bowiem działać chociażby w innych „środowiskach medialnych”, dla których literackość czy artystyczność budowana w kategoriach centrum może nie być żadnym wyznacznikiem (przykładem sa słowne pojedynki, przygadywanie, żart, dowcip). Paradoksalnie więc - w sytuacji obecności owych ,gorących" miejsc kultury, lokalnych i niezwykle ważnych form uczestnictwa w kulturze - rozpoznaje się tam pewien rodzaj ubytku, niepełnego rozwoju, gustu miernego ( „festyn”, „zabawa”).

To w tym kontekście działamy i wytwarzamy nasz zespołowy projekt. Chcemy stworzyć warunki, w których wspomniane miejsca kultury będą się ujawniały i przebudowywały, czy też odkształcały nasze własne myślenie o tym, co kulturalne, co obywatelskie - o rozwoju, o sztuce, o życiu społecznym. To projekt naszego działania w kulturze - etnograficznie zorientowanej animacji kultury. Na czym jednak dokładnie polega owa siła dekolonizująca, odwracająca zależności pomiędzy kulturowym centrum i kulturowymi peryferiami? Podałbym tu przede wszystkim trzy punkty, trzy miejsca, w których można podważyć dotychczasowy układ.

\section{/// 1. Proces zasadniczego odkształcania się projektu}

Idea tego projektu było zatem uznanie pewnej niezbywalnej, oddolnej energii: $z$ jednej strony przywoziliśmy ze soba pomysły na działania, z drugiej, one dopiero tam na miejscu powstawały. W naszych głowach pojawiły się wcześniej na przykład wizje pracy z przerabianymi i tuningowanymi w wiejskiej estetyce pojazdami, przejazdy ulica, pochód-parada z udziałem zbudowanych naprędce platform na kołach, a wszystko to ulegało przemianie w trakcie kolejnych przyjazdów. Same działania początkowo koncentrowały się wokół opowiadania o urządzeniach i pokazywania tego, co już zrobione. Później dopiero zaczęły się rzeczy nieplanowane 
i wymyślane spontanicznie w czasie spotkań - naprawienie gokarta, odkrywanie kolejnych konstruktorów, filmowanie wiejskich, młodzieżowych „fitness-klubów" przez Lukasza Skapskiego, przejazd czarną vectrą pod świetlicę na otwarcie koncertu bluesowego.

Proces tej animacji polega więc zatem przede wszystkim na ciagłym jego odkształcaniu i przebudowywaniu. W istocie jest to bezustanne myślenie, spotykanie się z ludźmi, wspólna praca, dzielenie się refleksjami, chwytanie tego, co „działa” w projekcie, co ma sens zarówno dla animatora-artysty, jak i dla ludzi, z którymi pracujemy; co podchwytuja, czemu nadaja własne znaczenia. Autorami tych odkształceń i przemian są zatem nie tyle animatorzy czy artyści, nie tyle sami ludzie, ile jednocześnie i jedni, i drudzy. Działanie „uciera” się pomiędzy nimi, „rozpędza”, „krystalizuje”. Z czego to wynika? Otóż właśnie to podskórne testowanie pracy - powstające nowe idee, złudzenia i możliwości - jest pewnym ukrytym, ale bardzo pracochłonnym procesem, w trakcie którego coś się wykształca, wydobywa. To wspólna przemiana świadomości, ale dokonuje się ona na granicy porozumienia; to przezwyciężanie trudu pierwszych interakcji które są niepewne, tworzą odmienne role, wiele tu wstydu, ociagania się, chwiejności. Jednak, jak zauważałem w trakcie działań, jakimś cudem z czasem zaczyna się przemiana, wydarzenia toczą się coraz szybciej, ludzie zaczynają się „gromadzić”. Nasze opisy działań z pierwszych miesięcy projektu i nasze rozmowy z broniowianami i ostałówczanami pełne są zatem takich odkształceń, chwilowych wypiętrzeń, ale i jednocześnie pod tym wszystkim ukryte są momenty wahań, trudne chwile budowania współpracy, rozpędzanie kołowrotu wydarzeń. A to znaczy, że pod projektem ukryta jest właśnie pewna ,podziemna rzeka” - nie tylko proces wspólnego działania, ale i proces wspólnego, nieraz powolnego i trudnego budowania interakcji, a w końcu przeistaczania - testowania tego, co wyobrażalne i co zarazem możliwe ${ }^{4}$. Co więcej, z tego wynika też coś bardzo istotnego, a mianowicie ciąg wydarzeń wyobrażonych, uruchomionych w naszych głowach, chwilami nawet opisanych, a które się nigdy nie odbyły. Ten katalog niedokończonych wydarzeń, interakcji i działań artystycznych, również plastyczny, zmienia się i faluje, odkształca wraz z naszą praca z ludźmi, z ich pragnieniami, pomysłami, $z$ ich terminarzem zajęć i najbardziej praktycznymi potrzebami.

\footnotetext{
${ }^{4}$ Projekt Prolog może być zatem także ujrzany w ciagu projektów, „gasnących strumieni”, które nie zostały zrealizowane, a które w pewnym momencie wydawały się najzupełniej realne i całkiem poważnie planowane; obecnie świadczą o nich często jedynie plansze i harmonogramy dopinające terminy, znaczące możliwości, planujące działania, a które w pewnym momencie rozjarzyły się i weszły we wspólne myślenie, nawet w samą akcję, po czym powoli zagasły.
} 


\section{/// 2. Nieprzewidywalność procesu}

To odkształcanie się projektu jest zatem tutaj efektem procesu bardziej wewnętrznego - żaden z projektów nie był właściwie przywieziony w gotowej formie, każdy rodził się na miejscu, nabierał swego sensu dopiero we współdziałaniu z mieszkańcami (choć przecież istniał wcześniej w głowach animatorów). To jednak, co tu niezwykle istotne, to owa aktywność podziemna, pewna część akcji, która pozostaje dopiero do odsłonięcia, wydobycia nie tylko w trakcie działań, ale i po ukończeniu projektu. Po zamknięciu projektu Prolog przyjeżdżaliśmy jeszcze kilkakrotnie z niewielkimi działaniami i ich kontynuacjami i dopiero wtedy widzieliśmy, jak inicjatywy projektowe zyskują efekty.

Punktem wyjścia były nasze relacje z mieszkańcami obu wiosek, wypracowane w trakcie działań animacyjno-artystycznych; często są to związki pewnej szczególnej bliskości i bezpośredniości, osiagane podczas wspólnego mieszkania, przebywania, brania udziału w życiu poszczególnych rodzin. Kolejne powitania i pożegnania pełne są uścisków, serdeczności, podarków, nieformalnych zwrotów, zdrobnień („Aluś”, „Rysio”, „Tomuś”, „Zdzichu”, „Zuzia”, „Stasio”). Czy jednak takie etnograficzne przeniknięcie „wewnątrz” środowiska Broniowa i Ostałówka, nawiązanie relacji z ludźmi, jest tym, co się rzeczywiście wydarzało? Pozostajemy tam też przecież jednocześnie obcy, różni, zresztą to, co dzieje się w terenie, w akcji, przemienia się często $z$ bliskich i pełnych fascynacji interakcji terenowych w chłodny analityczny ogląd (kiedy z zajmującej, pełnej dowcipu rozmowy przechodzimy za drzwi i tam, po cichu, zastanawiamy się, co właściwie usłyszeliśmy). Inaczej reagujemy, czego innego też oczekujemy od siebie wzajemnie, inne projektujemy wyobrażenia. Jest to olbrzymie obciążenie. Łączenie tych dwóch poziomów, tych dwóch wcieleń jest czymś niemal nieusuwalnym, jest osią etycznego napięcia i całej dwuznaczności projektu etnograficzno-animacyjnego, rozziewu pomiędzy nami. Odczucia własnej sytuacji, wyrazy pewnego wstydu pojawiały się często już w pierwszych słowach, zanim jeszcze się dobrze poznaliśmy; w każdym razie dopiero w takim kontekście widoczna stawała się pewna dwuznaczność naszego przyjazdu i całego procesu badań oraz akcji animacyjnych ${ }^{5}$. Pojawia się tu swoista mieszanina wchodzenia w bliskie relacje i zarazem

\footnotetext{
${ }^{5}$ Jest bowiem w tego typu badaniach pewna niepewność, pewna fałszywie pobrzmiewająca nuta $-z$ jednej strony jest badacz-animator, posłannik akademii, instytucji kultury, stowarzyszenia skupiającego animatorów, niosacy koncepcje „lokalnego rozwoju”, z drugiej zaś sama społeczność, ludzie i miejsca, z ich problemami, ich zubożeniem i poczuciem marginalizacji.
} 
profesjonalnej umiejętności wycofywania się, wytwarzania pewnego dystansu; z jednej strony zaangażowanie, z drugiej jednak - praca nad projektem, profesjonalizacja zachowań, rola „animatora”, „artysty” „etnografa”. Jednocześnie relacje z ludźmi powstaja powoli, stopniowo zawiązują się wspólne wydarzenia - zawsze na początku projekty ruszały z niejakim trudem, niczym zardzewiała maszyna, z czasem nabierając rozpędu.

$\mathrm{Na}$ tę sytuację można jednak spojrzeć inaczej, nie jak dotychczas - za pomocą kryterium pewnej zażyłości i współuczestnictwa - ale za pomoca pojęcia współudziału (complicity) George’a Marcusa (2003). O ile bowiem współuczestniczenie niesie w sobie owo oskarżenie o pomieszanie bliskości i profesjonalnego dystansu, ,pamiętaniu o swym zadaniu”, o tyle współudział wprost pozwala owe napięcia, różnice ról i motywacji nie tyle przekroczyć, co nawet wręcz wydobyć, przywrócić do istnienia, uczynić obecnym (a nie głęboko, gdzieś u spodu - skryć); uznać zatem za odmienne motywacje brania udziału w wydarzeniach artystyczno-animacyjnych dwóch stron, grupy projektowej i ludzi na miejscu. Marcus przywołuje tu oksfordzką definicje słowa complicity, jako oznaczającego z jednej strony „stan zaangażowania”, z drugiej „,współudział w przestępstwie”, przywołuje więc całą ambiwalencję tej sytuacji. W przeciwieństwie do poufałego współuczestnictwa (czyli relacji bliskości i zażyłości osiaganej w terenie), perspektywa ta wnosi ze sobą konieczność przyjęcia owego nieusuwalnego napięcia spotkania; wnosi trwale obecną, źródłową różnicę pomiędzy dwiema jego stronami, pomiędzy ludźmi. I tu jest chyba punkt kluczowy, niezbędny do zrozumienia tego, co dzieje się też w trakcie spotkań, widowisk, sytuacji etnograficznych, co dzieje się z pewną kumulująca się „podziemna rzeką”, z jej niespodziewanym przebiegiem i zaskakującymi konsekwencjami.

W tym miejscu jeszcze raz zwrócę się w stronę turnerowskiej antropologii - antropologii dramatu społecznego, ale rozumianego właśnie na podobieństwo współudziału wraz z całą swoją różnica, swoim ryzykiem i nierównowagą. Czy odmienność naszych ról, światów, z których się wywodzimy, celów i motywacji spotkań, świadczy o tym działaniu - można by zapytać - jako o czymś z obu stron „sztucznym”, „nieprawdziwym”? Czy było na przykład pewna podtrzymywaną „rolą, czy rzeczywiście wytwarzaliśmy po obu stronach pewne ciążące może nawet „role”, aby podtrzymywać interakcję? Oczywiście - do pewnego stopnia tak było. Myślę jednak, że można tu zmienić, przetworzyć nieco pojęcie tak przyjmowanej „roli”, i zarazem pojęcie czegoś, co nazwać by można „gra” czy „udawaniem”. Victor Turner (2005) pokazuje to bardzo wyraźnie: każda 
taka interakcja jest przecież przede wszystkim działaniem - ale w bardzo specyficznym znaczeniu angielskiego słowa acting: jest zarówno czynnościa, jak i odgrywaniem. W tym sensie można powiedzieć, że nasze pierwotne relacje, jeszcze z badań etnograficznych, które początkowo „ucinały” zawiązujące się interakcje - przechodziły od zaangażowania i bliskości (field) do dystansu i analizy (desk) - tutaj, przez przejście w relacje wytwarzane w obrębie animacji i sztuki, znalazły jakby możliwość przezwyciężenia, pewne ujście. W tym sensie współbycia - w sensie współudziału raczej niż współuczestnictwa, powstaje tu coś, co nazwałbym sytuacją działania etnograficznego i animacyjnego performansu. Choć nie jest to oczywiste, zachowanie obu stron pozostaje wówczas w nieustannym napięciu - jest naraz „powtarzane” $i$, ,wytwarzane” (na nowo), jest jakby „,sztuczne” i jednocześnie ,autentyczne”, „bliskie nam” i „obce”.

\section{/// 3. Niemechaniczne konsekwencje działania}

To, co następuje w tym projekcie, to więc przede wszystkim pewien ruch, „bieg akcji” (owa „podziemna rzeka”, która i wcześniej, i później towarzyszy całemu działaniu). Można też wstępnie przyjąć, że jest jednak też to, co dzieje się między ludźmi. To, co w tej sytuacji „międzyludzkie”, by użyć pojęcia Martina Bubera, to wydobycie ,ja” z wewnątrz ról społecznych i skierowanie ku temu, co nieprzewidywalne, zaskakujące, jak pokazywał Ryszard Michalski, swą autonomiczną siłą ${ }^{6}-$ ma charakter ukryty, podziemny i stopniowo nabiera rozpędu. A zatem, mam wrażenie, chodziło nam o to, aby projekt nie polegał na wywoływaniu „mechanicznego” efektu w społeczności czy wśród ludzi, nie polegał na stymulowaniu zmiany społecznej w pożądanym, zaprojektowanym wcześniej kierunku. Nie ma tu dla nas „mechanicznych” konsekwencji naszych działań, takich jak budowanie pewnych określonych postaw, kompetencji czy elementów życia społecznego.

Nie znaczy to jednak, że projekt ten nie znajduje swojego „silnego” przełożenia społecznego. Przynosi bowiem pewne poruszenie, translację artystyczno-społeczna, a więc coś, co daje realne efekty, pewną akcję, coś - co nagle się pojawia (niczym „bóg z maszyny”, opuszczany na linach na środek widowiska po to, aby znienacka odwrócił bieg wydarzeń). Nie jest to jednak zmiana społeczna, przynosząca pewien założony wcześniej efekt. $\mathrm{Na}$ czym więc polega? Otóż sądzę, że zarówno w samych wydarzeniach

\footnotetext{
${ }^{6} \mathrm{O}$ idei takiej pracy animacyjnej przeczytamy w wywiadzie z Ryszardem Michalskim i Violettą Pruską ze Stowarzyszenia Tratwa (Michalski, Pruska 2010).
} 
artystycznych, jak i obok nich obecna jest tu wciąż pewna stymulacja wydarzeń; we wszystkich tych wspólnych akcjach gdzieś obok zaczyna się społeczne „pobudzenie” związane z nowymi sytuacjami: ożywione rozmowy, niespodziewane zachowania, zebrania, decyzje nowych działań. Jest to logiczna kontynuacja odkształcania się projektu, jego dynamiki, pewnej nieprzewidywalności. Ta droga projektu rozwija się jednak dalej. Trudno jest tu znaleźć dobre słowo, ale składa się ona z owych niemechanicznych, opóźnionych jakby reakcji („precypitacja wydarzeń”).

Te wspólne działania, wspólne zaangażowanie w projekt przynosi zatem, rzekłbym, pewne „procesy wewnętrzne”, biograficzne turn-takings, pozostające wewnątrz doświadczeń i w niespodziewany sposób dające o sobie znać. Te doświadczenia, mam wrażenie, że niezwykle intensywne, związane z „przekraczaniem siebie”, przebudowują sposób myślenia, tworzą pewne biograficzne „punkty nawigacyjne” - mogą one później jakby zmieniać pojedyncze biografie ludzi, pamięć ich doświadczenia, w końcu sposób życia, społecznego działania. To „przekraczanie siebie” przywraca tutaj w ogóle, można by rzec, zdolność do „bycia sobą”, a więc do bycia kimś innym; do odmiany, do życia „tysiącem żyć” (Rapport 2010) - także we wspólnocie.

\section{/// Zakończenie: „trzecia” logika działania}

Projekty community arts i działania sztuki krytycznej związane są często z realizacja pewnych określonych celów i zamierzeń - z pewną „silną" skutecznością (powolna). W projekcie Prolog i Etnografia/Animacja/Sz̨tuka same cele działania sa nieco inne, a nawet - zupełnie inne. Mamy tutaj raczej do czynienia zaledwie z tworzeniem warunków, sytuacji, w których możliwe jest pojawianie się i odkotwiczanie (take-off) pewnych nieprzewidywalnych mechanizmów „wywiązywania się” zmiany. Takie efekty mają najczęściej „podziemny” charakter kumulacji, nabierają swej dynamiki powoli, aż wreszcie nagle stają się widoczne (,precypitacja wydarzeń”). Widać to w wydarzeniach pojawiających się jakby na zasadzie deus ex machina następujących po naszych działaniach, objawiających się w zaskakujący sposób, czasem w miarę szybko, niemal natychmiast, często zaś wiele miesięcy po ich zakończeniu. 
Te reakcje ${ }^{7}$, te opowieści i działania, pojawiają się zatem trochę na zasadzie „cudu”, nieoczywistego zachowania, to coś, co zaskakuje, gdzieś w utajeniu precypituje, a następnie nagle się pojawia. Coś się w tych momentach ujawnia - czego nie widać, a co „daje o sobie znać”. Narastaja w ten sposób pewna energia i pewien ruch wokół kolejnych wydarzeń, nabierają zaskakującego tempa. Zmiana, jeśli zachodzi, ma charakter zmiany ,nieoczekiwanej” i ulokowanej wewnątrz pojedynczych biografii (w ,wewnętrznych zwrotach" jednostek). To jakby proces stymulacji ról i działań odgrywanych przez wszystkich aktorów projektu, co skutkuje następnie wydobyciem się na powierzchnię pewnej trzeciej, zaskakującej uczestników logiki spotkania. Ta trzecia, powstająca na naszych oczach logika wydarzenia, to coś, co Erika Fischer-Lichte (2008) w obrębie sztuk performatywnych nazwała „emergencją znaczenia”. To jednak właśnie ten moment, w którym zmienia się sens działań ludzi i artystów, etnografii i animacji. Rodzą się nowe znaczenia i nowe, wspólne symbole; powstaje sytuacja, która przekracza zarówno plany animatorów, jak i lokalne sposoby życia.

\section{Bibliografia:}

\section{/// Alexander B.K. 2009. Etnografia performatywna. Odgrywanie i pobudzanie kultury, tłum. Ł. Marciniak, [w:] Metody badań jakościonych, t. 1, red. N.K. Denzin, Y.S. Lincoln, Wydawnictwo Naukowe PWN, Warszawa.}

\footnotetext{
${ }^{7}$ Podam jeszcze kilka przykładów. Przy okazji projektu Wojtka Ziemilskiego i Doroty Ogrodzkiej, w którym poszczególni mieszkańcy Ostałówka wyobrażali sobie coś, co chcieliby „widzieć” na miejscu dzikich nieużytków wokół wsi (a po kilku dniach stają tam ponownie, zasłaniając zarastające krzaki stworzonym przez Wojtka fotowizerunkiem), jeden z nich widzi tam „ranczo”. Już kilka dni później - podczas wieczornego spotkania z mieszkańcami - kiedy na biała ścianę budynku rzucane są z projektora zdjęcia „ugorów” i ludzi przykrywających je swymi wyobrażeniami, przybywa on znienacka w przebraniu, w „ranczerskich” butach kowbojkach i w pięknym skórzanym kapeluszu. Podobnie, kilka dni po pokazie projektu „Ugory” w Ostałówku, nasi znajomi robią dla nas ognisko z tańcami, na polu, za obejściem, na które rzucają światła stroboskopu: sama ta impreza i jej wspólne przygotowanie jest czymś niezwykłym dla nich samych - jak się dowiadujemy, to dla nich szczególne przedsięwzięcie. Ale to właśnie wtedy też pojawiają się tam głosy i doświadczenia, które wydobywają się dzięki projektowi - w nocy na polach rozświetlonych stroboskopem jeden z młodych ludzi opowiada mi na przykład o dzikich kaczkach, które kiedyś przyniósł z rozlewiska i dołączył je do kaczek domowych - chciał, żeby żyły razem; była to opowieść „zaskakująca”, było to, jak zauważyłem, dla niego ważne i wybrane z życia wydarzenie, związane z pewną , liminalną”, uwalniającą wyobraźnią; była to najlepsza rzecz, jaką chciał mi wtedy przekazać. W tym samym odruchu, kiedy znów kilka tygodni później w świetlicy wiejskiej odbywa się koncert bluesowy Jarka i Gwidona z udziałem utalentowanego muzyka, chłopca z sąsiedniej wsi, jeden z mężczyzn wyciagga mnie na zewnątrz i tam opowiada z przejęciem, jak dla żartu wymontowywali w dzieciństwie w noc świętojańską bramy z obejść sąsiadów i wrzucali je do sadzawki na środku wsi.
} 
/// Binder Th., red. 2005. Between Estrangement and Familiarization: Co-Constructing Images of Use and User in Collaborative Design, [w:] Design Spaces, red. Th. Binder, M. Hellström, Edita Publishing, Kopenhaven.

/// Carr W. 2010. Filozofia, metodologia $i$ badania w działaniu, tłum. K. Liszka, [w:] Badania w dżiataniu. Pedagogika i antropologia zaangażowane, red. H. Červinkowá, B. D. Gołębniak, Wydawnictwo Naukowe Dolnośląskiej Szkoły Wyższej, Wrocław.

/// Crehan K. 2011. Community art. An Anthropological Perspective, Berg Publishing, Oxford.

/// Červinkowá H., red. 2010. Badania w džiałaniu. Pedagogika i antropologia zaangażowane, Wydawnictwo Naukowe Dolnośląskiej Szkoły Wyższej, Warszawa.

/// Fischer-Lichte E. 2008. Estetyka performatymności, tłum. M. Borowski, M. Sugiera, Księgarnia Akademicka, Kraków.

/// Foster H. 2012. Powrót Realnego. Awangarda u schyłku XX wieku, tłum. M. Borowski i M. Sugiera, Universitas, Kraków.

/// Gandhi L. 2008. Teoria postkolonialna. Wprowadzenie krytyczne, thum. J. Serwański, posł. E. Domańska, Wydawnictwo Poznańskie, Poznań.

/// Godlewski G. 2002. Animacja i antropologia, [w:] Animacja kultury. Dośniadczenie i praysz̨ość, red. G. Godlewski, I. Kurz, A. Mencwel, M. Wójtowski, Instytut Kultury Polskiej UW, Warszawa.

/// Godlewski G., red. 2002. Animacja kultury. Doświadczenie i praysszłość, Instytut Kultury Polskiej UW, Warszawa.

/// Godlewski G. 2005. Potę̇ne zbiorniki znnacz̧eń, wywiad z Grzegorzem Godlewskim, „Op.cit.” 2005, nr 24-25, s. 6-7.

/// Grotowski J. 1972. Święto, „Odra” 1972, nr 6, s. 47-51.

/// Hastrup K. 2006. O ugruntowywaniu sie swiatón - podstawy empiryczne antropologii, tłum. M. Bucholc, [w:] Badanie kultury. Elementy teorii antropologicznej. Kontynuacje, red. M. Kempny, E. Nowicka, Wydawnictwo Naukowe PWN, Warszawa.

// / Hastrup K. 1998. Poza antropologia. Antropolog jako przedmiot przedstawienia dramatycznego, tłum. G. Godlewski, „Polska Sztuka Ludowa. Konteksty” 1998, nr 2, s. 20-28. 
/// Jabłońska E. 2011. Lagodna przewrotność - oto mój ideat, z Elżbietą Jabłońską rozmawia Emilia Iwanciw, [w:] Nadzwyczaj nieudane dzieło, katalog wystawy E. Jabłońskiej, Galeria Sztuki w Olsztynie/Bunkier Sztuki Kraków.

/// Kuroń D. 2009. Cyy autonomiczne organizacje spoteczne sq nam potrzebne? http://www.krytykapolityczna.pl/Opinie/Kuron-Czy-autonomiczneorganizacje-spoleczne-sa-potrzebne/menu-id-197.html;dostęp: 15.12.2011. // / Kurz I. 2008. Lokalnie. Community arts/ animacja kultury, Instytut Kultury Polskiej UW, Warszawa.

/// Kwiatkowska O. 2007. Lucim, cayli konsekwencje pewnego projektu, [w:] Zaangażowanie çy izolacja? Strategie społecznej egzystenciji bumanistów, red. J. Kowalewski, W. Piasek, Wyd. UWM/Colloquia Humaniorum, Olsztyn.

/// Leavy P. 2009. Method Meets Art. Arts-Based Research Practice, Guilford Press, New York.

/// Liep J., red. 2001. Locating Cultural Creativity, Pluto Press, London.

/// Marcus G. 1995. Ethnography in/ of the Word System: The Emergence of Multi-Sited Ethnography, „Annual Review of Anthropology” 1995, nr 24, s. 95-117.

/// Marcus G. 2003. Użyteczność kategorii uczestnictwa w zmieniajacych sie kontekstach antropologicznych badan terenowych, tłum. J. Jaxa-Rożen, [w:] Clifford Geert: Lokalna lektura, red. M. Brocki, D. Wolska, Wydawnictwo Uniwersytetu Jagiellońskiego, Kraków.

/// Matarasso F. 2009. Pośród nateżonego ruchu. Istota wtaczenia w kulture, „Kultura Współczesna» 2009, nr 4, s. 23-31. .

/// Mencwel A. 2009. Etos lewicy. Esej o narodzinach kulturalizmu polskiego, Wyd. Krytyki Politycznej, Warszawa.

/// Mencwel A. 2006. Wyobrażnia antropologičnna. Próby i studia, Wydawnictwa Uniwersytetu Warszawskiego, Warszawa

/// Michalski R., Pruska V. 2010. Wedrowcy ziemi Nod..., z Ryszardem Michalskim i Violetta Pruską rozmawia Barbara Markowska, [w:] „Po co pamietać razem?". Praktyki pamieci a kultura obywatelska kobiet w gminie Stare Juchy i w powiecie etckim, red. B. Markowska, Collegium Civitas, Warszawa.

/// Morawski J., Morawska I. (reż.). 2010. Czekajac na sobote (film), prod. Polska. 
/// Mosse D. 2006. Anti-social anthropology? Objectivity, objection, and the ethnography of public policy and professional communities. "Journal of the Royal Anthropological Institute" 2006, nr 12, s. 935-956.

/// Ptak A. 2008. Community arts. Wprowadrenie do idei, [w:] Lokalnie. Community arts/ animacja kultury, red. I. Kurz, Instytut Kultury Polskiej UW, Warszawa.

/// Rapport N. 2010. Apprehending Anyone. The Non-Indexical, Post-Cultural and Cosmopolitan Human Actor, ,Journal of Royal Anthropological Institute” 2010, nr 1, s. 84-101.

/// Reason P., Torbet W. 2010. Zwrot dziataniowy. Ku transformacyjnej nauce społecznej, [w:] Badania w dżiałaniu. Pedagogika $i$ antropologia zaangażowane, red. H. Červinkowá, B. D. Gołębniak, Wydawnictwo Naukowe Dolnośląskiej Szkoły Wyższej, Wrocław.

// / Reksnis D. bd. Sztuka (hasło), [w:] Terą! Animacja kultury, Stowarzyszenie Katedra Kultury, Warszawa.

/// Rogozińska A. 2009. Animacja kultury a zmiana spoteczna w kontekśscie community arts $i$ community cultural development, „Kultura Współczesna” 2009, nr 4, s. 90-102.

/// Scheper-Hughes N. 2010, Prymat etyki. Perspektywa walczacej etnografii, tłum. K. Liszka, [w:] Badania w driałaniu. Pedagogika i antropologia zaangażowane, red. H. Červinkowá, B.D. Gołębniak, Wydawnictwo Naukowe Dolnośląskiej Szkoły Wyższej, Wrocław.

/// Scott J. 1990. Domination and the Arts of Resistance. Hidden Transcripts, Yale University Press, New Haven.

/// Skapski L. 2009. Masæyny. „Samy” z Podhala, Fundacja Sztuk Wizualnych, Kraków.

/// Svašek M. 2007. Antbropology, Art and Cultural Production, Pluto Press, London.

/// Tax S. 2010. Projekt Lisy, tłum. A. Kościańska i M. Petryk, [w:] Badania w driałaniu. Pedagogika $i$ antropologia zaangażowane, red. H. Červinkowá, B.D. Gołębniak, Wydawnictwo Naukowe Dolnośląskiej Szkoły Wyższej, Wrocław.

/// Terą! Animacja kultury, bd., Stowarzyszenie Katedra Kultury, Warszawa.

/// Turner V.W. 2005. Od rytuatu do teatru. Powaga zabawy, tłum. M. i J. Dziekanowie, Oficyna Wydawnicza „Volumen”, Warszawa. 
/// Wasilewski J. 2012. Jesteśmy potomkami chłopów, z prof. Jackiem Wasilewskim rozmawia Marta Duch-Dyngosz, „Znak” 2012, nr 684, s. 14-17.

/// Willis P. 2005. Wyobrą́nia etnografična, tłum. E. Klekot, Wydawnictwo Uniwersytetu Jagiellońskiego, Kraków.

/// Wright Ch., Schneider A. 2010. Between Art and Anthropology. Contemporary Ethnographic Practice, Berg Publishing, Oxford.

/// Wright Ch., Schneider A. 2006. Contemporary Art and Anthropology, Berg Publishing, Oxford.

/// Żmijewski A. 2007. Stosowane sztuki społeczne, „Krytyka Polityczna” 2007, nr 11-12, s. 14-24.

\section{/// Abstrakt}

W tekście staram się odpowiedzieć na pytanie, jak wprowadzać elementy działania za pomocą sztuki w środowiskach wiejskich, często peryferyjnych, nie budując jednocześnie pozycji wyższości i dominacji. Przedstawiam projekt animacyjny Prolog. Nierozpoznane uymiary rozwoju kulturalnego z roku 2011, a następnie jego rozwinięcie Etnografia/Animacja/Sz̨tuka z 2012 roku, który od kilku lat prowadzimy wraz z całym zespołem animatorów, artystów i etnografów w wioskach w okolicach Szydłowca, w miejscach dotkniętych na dużą skalę nieopłacalnością drobnego rolnictwa i lokalnym, niekończącym się bezrobociem.

Pokazuję, jak badania etnograficzne stopniowo ugruntowują i ubogacaja animację oraz jak animacja kultury tworzy jednocześnie sytuacje badawcze, w których rzeczywistość etnograficzna staje się „gęsta”, staje się aktualnym widowiskiem i dynamicznym działaniem kulturowym. Staram się pokazać, jak etnografia w połączeniu $z$ działaniami animacyjnymi stwarza warunki, by ujawniło się to, co bardzo istotne w życiu tych społeczności - niejawny wymiar ich twórczego działania i ich oddolna, spontaniczną samoorganizację. Buduję $\mathrm{w}$ ten sposób metodologiczną perspektywę działania w kulturze, której celem jest nie tyle wywołanie „mechanicznych” efektów i zmiany społecznej, ile stworzenie wspólnego, kulturotwórczego wydarzenia o nieprzewidywalnych i emergentnych rezultatach.

Słowa kluczowe:

etnografia, sztuka, badania w działaniu, animacja kultury, emergencja znaczenia 


\section{/// Abstract}

The purpose of my text is to answer the question: how to introduce elements of the art to rural areas, without establishing at the same time relations of superiority and domination. To this, I reconstruct project Prologue. Unrecognized dimensions of cultural development from 2011, and then its extension, Ethnography/Animation/Art, from 2012. Both projects were led by a team of animators, artists, and ethnographers in the villages in the vicinity of Szydlowiec, in areas of unprofitable, small-scale agriculture, affected by local, permanent unemployment.

Ethnographic research gradually enrich and ground animation, while animation brings about quasi-experimental research situations, in which ethnographic reality becomes "thick" and dynamic. I try to show how ethnography combined with animation reveals what is the most important in the life of the community - an implicit dimension of creative work, bottom-up, spontaneous self-organization. It is in this way that a new methodological perspective on action comes about. Its aim is not so much to induce "mechanical" social change as to construct common, creative event with unpredictable and emergent effects.

Keywords:

ethnography, art, action research, cultural animation, emergence of meaning 